УДК 658.114:622.7

Шагоян C.M.

ДВНЗ "Національний гірничий університет»

Солодовник Л.М.

докт. техн. наук., професор,

ДВНЗ "Національний гірничий університет»

Черненко Н.O.

канд. економ. наук, дочент

Національний технічний університет Украӥни «КПI»

\title{
ОЦІНКА ВПЛИВУ КОРПОРАТИВНОЇ СИНЕРГІЇ ТА КОМПЛЕКСНОГО ВИКОРИСТАННЯ СИРОВИНИ НА ЕКОНОМІКУ АСОЦЙОВАНОГО ГІРНИЧО-ЗБАГАЧУВАЛЬНОГО ПІДПРИЕМСТВА
}

\author{
ОЦЕНКА ВЛИЯНИЯ КОРПОРАТИВНОЙ СИНЕРГИИ И КОМПЛЕКСНОГО \\ ИСПОЛЬЗОВАНИЯ СЫРЬЯ НА ЭКОНОМИКУ АССОЦИИРОВАННОГО ГОРНО- \\ ОБОГАТИТЕЛЬНОГО ПРЕДПРИЯТИЯ
}

\section{ASSESSMENT OF THE IMPACT OF CORPORATE SYNERGY AND COMPLEX USING OF RAW MATERIALS ON THE ECONOMY OF THE ASSOCIATED MINING AND MINERAL PROCESSING COMPANY}

Визначені фактори до оцінки потенційного синергетичного ефекту для гірничозбагачувального підприємства, асочійованого з вертикально-інтегрованим холдингом. Запропоновано аналітичні вирази для розрахунку рівня беззбитковості, чистого грошового потоку асоційованого підприємства, зокрема при збільшенні обсягів продажів супутніх корисних копалин. Обгрунтовано метод оцінки рівня самофінансування асоиійованого гірничо-збагачувального підприємства в контексті його потреб для оновлення та оптимізації виробничих потужностей. Отримані аналітичні вирази, які дозволяють оцінити граничні обсяги реалізаиії продукиіiі, при яких підприємство самостійно фінансує власну виробничо-господарську діяльність. Визначено метод розрахунку величини стабілізаційного фонду асоиійованого підприємства на основі коефіцієнту попиту, щзо забезпечуватиме його економічну безпеку в системі відносин з іншими підприємствами холдингу.

Ключові слова: вертикально-інтегрований холдинг, гірничо-збагачувальне підприємство, синергія, самофінансування, стабілізаційний фонд, комплексне використання сировини.

Определены факторы к оценке потенииального синергетического эффекта для горно-обогатительного предприятия, ассоциированного с вертикально-интегрированным холдингом. Предложены аналитические выражения для расчета уровня безубыточности, чистого денежного потока ассоциированного предприятия, в частности при увеличении объемов продаж сопутствующих полезных ископаемых. Обоснован метод оценки уровня самофинансирования ассоциированного горно-обогатительного предприятия в контексте его потребностей для обновления и оптимизации производственных мощностей. Полученные аналитические выражения, позволяющие оценить предельные объемы реализации продукции, при которых предприятие самостоятельно финансирует свою 
производственно-хозяйственную деятельность. Определен метод расчета величинь стабилизачионного фонда ассочиированного предприятия на основе коэффициента спроса, обеспечивающего его экономическую безопасность в системе отношений $c$ другими предприятиями холдинга.

Ключевые слова: вертикально-интегрированный холдинг, горно-обогатительное предприятие, синергия, самофинансирование, стабилизационный фонд, комплексное использование сырья.

The factors to evaluate the potential synergies for ore mining and processing enterprises, associated with a vertically integrated holding. The analytical expression for the calculation of the break-even level, the net cash flow associated companies, in particular with an increase in sales of associated minerals. Based methods of assessing the level of self-financing of the associated mining and processing enterprise in the context of its needs for the renovation and optimization of production capacity. The analytical expressions to assess the marginal sales volumes of products for which the company finances its own production and economic activity. Determine the method of calculating the value of the stabilization fund of the associate on the basis of demand factor, ensuring its economic security in the system of relations with other holding companies.

Keywords: vertically integrated holding company, mining and processing enterprises, synergy, self-financing, the stabilization fund, the integrated use of raw materials.

Вступ. Економіка підприємства формується в процесі управління його господарською діяльністю, що забезпечує досягнення виробничих, комерційних, соціальних та інших результатів. Особливості процесу управління визначаються багатьма чинниками, зокрема галузевою належністю підприємства, масштабом діяльності, впливом на довкілля, специфікою організаційно-правової форми господарювання. 3 урахуванням вагомої частки гірничо-металургійного сектору в економіці України та його значення для розвитку будівельної та інших видів діяльності актуальною $\epsilon$ оцінка економіки гірничо-збагачувального підприємства 3 урахуванням його мінерально-сировинних обмежень. Істотним чинником гірничозбагачувального підприємства, на нашу думку, $\epsilon$ його залежність від холдингової вертикально-інтегрованої компанії, що обумовлює статус асоційованості, але також утворює підгрунтя корпоративних синергетичних ефектів, які впливатимуть на вирішення питань 3 розвитку мінеральносировинної бази підприємства.

Питання синергетичних аспектів взаємодії корпоративного об'єднання (його учасників) та асоційованого підприємства розглядаються багатьма вченими. Вагомий внесок до теоретичних засад зазначених напрямків висвітлено в роботах вітчизняних та зарубіжних економістів: В.М. Добровського, А.Г. Загороднього, М.В. Задорожнього, А.М. Герасимовича, Л.М. Кіндрацької, В.Г. Лінника, О.А. Петрик, О.М. Петрука, М.Г. Чумаченка, Й. Бетге, А. Беррі, М.Ю. Медведєва, М.Р. Метьюса, В.Ф. Палія, Ч. Хорнгрена. Сталим залишається інтерес науковців до питання 
оцінки синергетичних ефектів від об'єднання підприємств [1]. Проте, недостатньо приділяється уваги питанням комплексного використання сировини гірничо-збагачувального підприємства (далі ГЗП). Тому метою дослідження $\epsilon$ розробка методичних положень та підходів оцінки впливу корпоративної синергії та комплексного використання сировини на економіку асоційованого ГЗП.

Постановка завдання. Ефективність роботи підприємства в складі холдингу грунтується на кількості делегованих повноважень щодо децентралізованого управління підприємством та їх змісті. Від холдингу можуть залежати обсяги реалізації та ціна продукції комбінату, відбувається перерозподіл адміністративних витрат, формується виробнича програма, фінансуються науково-дослідні роботи та здійснюються інші заходи підтримки конкурентоспроможності гірничо-збагачувального підприємства та його продукції. Тому, в основу роботи покладено, що довгострокове стала робота ГЗП, які входять до вертикально-інтегрованої структури залежать від впливу корпоративної синергії, відповідності його продукції потребам споживачів та комплексного використання сировини.

Методологія. В основу дослідження покладена концепції раціонального та комплексного надрокористування, синергізму, які разом формують особливості корпоративних відносин між виробничими підприємствами вертикально-інтегрованого холдингу. Дослідження виконано на прикладі відкритої звітної інформації гірничо-металургійного холдингу ТОВ «Метінвест» та його асоційованого підприємства - ПАТ «Центральний гірничо-збагачувальний комбінат». Досягнення мети статті передбачає:

- визначення ролі корпоративної синергії холдингу в питанні економічної безпеки асоційованого гірничо-збагачувального підприємства 3 огляду на його забезпеченість мінеральною сировинною;

- аналітичний опис взаємозв'язку економічних та фінансових результатів господарювання з виокремленням потенціального синергетичного ефекту для асоційованого підприємства;

- обгрунтування методу оцінки рівня самофінансування асоційованого гірничо-збагачувального підприємства в контексті його потреб для оновлення та оптимізації виробничих потужностей;

- визначення методу розрахунку величини стабілізаційного фонду асоційованого гірничо-збагачувального підприємства на основі коефіцієнту попиту з метою забезпечення його економічної безпеки в системі відносин 3 іншими підприємствами холдингу, що пов'язано 3 рівнем використання видобуваємих та акумульованих техногенних ресурсів гірничозбагачувального підприємства.

Для вирішення поставлених завдань використані наступні загальні та спеціалізовані методи наукового дослідження: аналітичний - при визначенні 
характеру впливу корпоративної синергії холдингу та комплексного використання сировини на результати діяльності асоційованого підприємства; елементи функціонально-вартісного та проектного аналізу - при оцінці стану самофінансування асоційованого підприємства та його потенціалу утворювати стабілізаційний фонд.

Результати дослідження. В практиці управління підприємствами гірничо-металургійного та енергетичного комплексу спостерігається утворення вертикально-інтегрованих об'єднань. Прикладом вертикально інтегрованої компанії з сильними позиціями на всіх етапах ланцюжка створення вартості від видобування руди до постачання кінцевого металургійного продукту споживачам може стати міжнародний гірничометалургійний холдинг «Метінвест». Виробничі потужності «Метінвесту» спрямовані на задоволення власних потреб в сировині, сталі та напівфабрикатах, а також забезпечення відповідних потреб значної частини українських, європейських та азійських металургійних підприємств. Стратегічні цілі холдингу - набуття лідерських позицій на європейському/світовому ринках, формування глобальної конкурентоспроможності холдингу - визначають рівень вимог до продукції більш ніж 20 асоційованих підприємств в різних країнах. Напрямок розвитку «Метінвесту» передбачає подальшу вертикальну інтеграцію до поглибленого переділу, збільшення обсягів виробництва шляхом будівництва або придбання підприємств.

Координація активів вугільної, гірничорудної, коксохімічної, металургійної та трубної галузей ТОВ «Метінвест Холдинг» здійснюється керуючою компанією, яка має дивізіональну структуру побудови бізнесу, що відповідає корпоративним принципам зі забезпечення високої інвестиційної привабливості і прозорості. Гірничорудні підприємства виробляють залізорудний концентрат та обкотиші, а також інші види сировини, яка повністю забезпечує потреби металургійних комбінатів холдингу, а також постачається іншим споживачам. Тому, пріоритетом гірничорудного дивізіону є забезпечення якості продукції, збільшення обсягів виробництва, розширення географії бізнесу та укладання довгострокових угод. В групу «Метінвест» також входять збутові, логістичні та транспортні (наприклад, Дунайська судноплавна стівідорна компанія) підприємства, які здійснюють підтримку корпоративного бізнесу. Об'єднання різних компаній спрямовано на отримання міжгалузевої синергії для підвищення ефективності бізнесу окремих підприємств та холдингу в цілому.

Оцінка впливу корпоративної синергії та комплексного використання сировини на економіку роботи підприємства розглядається 3 метою досягнення його стратегічної мети у результаті усіх видів діяльності. Для гірничо-збагачувального підприємства поступове погіршення гірничо- 
геологічних умов розробки родовищ у межах гірничих відводів ставить завдання забезпечення доступу до нових ділянок. Взаємозв'язок характеристик мінерально-сировинних запасів та економічних результатів гірничо-збагачувальних комбінатів є опосередкованим, оскільки вагому роль відіграють залучені технології та техніка, рівень організації праці, мотивація персоналу, а також, передусім, попит на збагачену рудну сировину. Специфічною особливістю економічної безпеки гірничо-збагачувальних підприємств слід визначити залежність від стану мінерально-сировинної бази.

Наприклад, ПАТ «Центральний гірничо-збагачувальний комбінат» (далі ЦГЗК) виробляє залізорудні обкотиші, залізорудний концентрат та щебінь [2]. Будівельний щебінь $є$ супутнім продуктом, оскільки він $є$ технологічними відходами процесу збагачення бідних та некондиційних кварцитів 3 вмістом заліза $12-14 \%$. Для підвищення рівня вмісту цінного компоненту в продукті до такого, який потрібний на ринку застосовують різні технології, серед яких найбільш поширеною $є$ збагачення сирої руди на збагачувальних фабриках. Геологічні особливості сировинної бази ЦГЗК характеризуються високими коефіцієнтами розкриття, значною відстанню транспортування руди 3 кар'єрів на дробильну фабрику. Через це, собівартість продукції на ЦГЗК є дещо вищою, ніж на інших залізорудних комбінатах Кривбасу. Слід зазначити, що у групі криворізьких гірничо-збагачувальних комбінатів (Центральний, Північний, Південний, Інгулецький) простежується відмінність номенклатури залізорудних продуктів, що обумовлено характеристиками рудної сировини та технологічними особливостями їі подальшого переділу.

Сировиною для виробництва залізорудної продукції (концентрату та обкотишів) є залізна руда власного видобутку, вапняк, бентоніт, металеві кулі. Особливістю складу постачальників сировини на ЦГЗК $є$ те, що вапняк та металеві кулі постачаються підприємствами холдингу. Проте ціни на сировину і матеріали залежать від загальних ринкових тенденцій: інфляція, курс іноземної валюти, державної митної політики. На думку фахівців комбінату, монопольне становище їх постачальників на ринку виробників і розпорядників сировини та матеріалів є додатковим чинником динаміки цін та тарифів [3]. Цим обумовлений ризик погіршення економічної безпеки ЦГЗК та пріоритетні напрямки внутрішніх удосконалень - зменшення ресурсоємності виробництва, яка обумовлена технологічними рішеннями та потребує інвестицій [4].

На національному ринку залізорудна сировина (ЗРС) в переліку споживачів та конкурентів ЦГЗК присутні економічні суб'єкти корпоративної групи (ПАТ "Єнакієвський металургійний комбінат" ПАТ "Металургійний комбінта «Азовсталь»", ПАТ "Алчевський металургійний комбінат ", ПАТ "ММК ім. Ілліча"), що може по-різному відбитись на економічній безпеці ЦГЗК. Довгострокові відносини з металургійними комбінатами сприймається 
як позитивне явище, але конкуренція між комбінатами холдингу (Північний, Центральний та Інгулецький ГЗК) утворює додатковий ризик в діяльності, оскільки показники якості залізорудної сировини (ЗРС) всіх виробників на регіональному ринку відрізняються незначно, тому постачальник ЗРС може бути замінений без технологічних наслідків для металургійних комбінатів. Забезпечення економічної безпеки асоційованого гірничо-збагачувального комбінату в такій ситуації обумовлена виваженістю портфельної політики холдингової компанії, спрямованості на збереження потенціалу комбінату в довгостроковому періоді.

Отже, асоційований гірничо-збагачувальний комбінат не самостійний в питанні обирання власних напрямків та способів розвитку. Оскільки холдинг має власні інтереси, а у найгіршій ситуації (криза) може позбутись комбінату (продати акції або ліквідувати підприємство) економічна безпека останнього визначається, насамперед, забезпеченням відповідності продукції потребам внутрішніх споживачів групи, які формують більшу додану вартість. Перебування гірничо-збагачувального комбінату у складі корпоративної групи пов'язано з ії портфельною стратегією, яка обумовлена:

- доцільністю утримання та розвитку окремого підприємства як прибуткового активу з урахуванням інвестицій;

- синергетичною або конгломератною логікою портфельної стратегії бізнес-групи;

- наявністю та якісними показниками предмету праці - запасів основної мінеральної сировини родовища;

- витратами, пов'язаними із забезпеченням виробничої діяльності комбінату прогресивною технікою, технологіями та кваліфікованим персоналом;

- організаційно-правовими та екологічними чинниками здійснення господарської діяльності тощо;

- перспективною оцінкою економічної безпеки гірничозбагачувального комбінату із урахуванням потенціалу диверсифікації його бізнесу на підставі комплексного використання мінерально-сировинних запасів в межах гірничого відводу.

Комплексне, повне використання мінеральної сировини повинно передбачати максимальну утилізацію відходів виробництва. В цьому аспекті збереження мінерально-сировинної бази комбінату відбувається шляхом використання техногенного ресурсу - пісків шламосховищ [5]. Обсяг виробництва концентрату 3 пісків суттєво коливається та не співпадає 3 динамікою виробництва рудного концентрату. Це дозволяє по даним інституту Кривбаспроекту зменшить собівартість виробництва концентрату на $30 \%$ в порівнянні 3 їх виробництвом 3 кварцитів поточного видобутку, зменшення відводу нових земель для складування відходів, а також 
зменшення негативного впливу на навколишнє середовище.

Відомо, що придбання та поглинання холдингом різноманітних підприємств покликано забезпечити або конгломератний ефект 3 усередненням підприємницького ризику бізнес-портфелю холдингу, або синергетичний ефект на підставі більш ефективного використання спільних ресурсів холдингу. Синергетичні ефекти в межах вертикально-інтегрованого холдингу ТОВ «Метінвест» виникають внаслідок багатьох чинників різної природи, зокрема:

- завантаження виробничих потужностей асоційованих гірничозбагачувальних підприємств 3 орієнтацією на потреби в залізорудній продукції з боку асоційованих металургійних заводів холдингу. Загальний обсяг залізорудної сировини, що виробляється на гірничо-збагачувальні комбінатах холдингу вдвічі перевищує іï потреби 3 боку металургійних заводів холдингу [6]. Тобто майже 50 \% виробленої залізорудної продукції це гарантований обсяг збуту, за умов сталої кон'юнктури ринків металургійної продукції. Буде доцільним зауважити, що частка окремого асоційованого гірничо-збагачувального підприємства в зазначених обсягах $\epsilon$ віддзеркаленням його економічної безпеки: визначає поточний статус для холдингу та окреслює способи його підтримування;

- централізації збуту продукції холдингу, зокрема через єдине Управління, яке відповідає за реалізацію залізорудної сировини всіх асоційованих гірничо-збагачувальних комбінатів, в тому числі на закордонних ринках;

- централізації логістичної діяльності шляхом організації та обслуговування перевезень вантажів в Україні та за іiі межами (послуги асоційованим комбінатам від транспортно-експедиторської компанії холдингу ТОВ «Метінвест-шиппінг») [7];

- забезпечення конкурентних переваг (прим. - у виробництві сталі) за рахунок оптимізації витрат асоційованих підприємствам на закупівлі шляхом централізації цієї функції та використання єдиних стандартів закупівельної діяльності в холдингу (послуги Дирекції холдингу із закупівель);

- зменшення частки постійних витрат за рахунок централізації вище зазначених сервісних функцій дозволяе відповідно зменшувати собівартість продукції, обумовленої комплексним використання корисних копалин.

Отже, синергетичні ефекти для холдингу в цілому визначаються потенціалом асоційованих підприємств створювати та реалізовувати конкурентоспроможну продукцію найвищого технологічного переділу холдингу - сталь. Синергетичні ефекти для асоційованого гірничозбагачувального підприємства забезпечують його виробничу потужність та комерційні діяльність, але ці ефекти за ознакою впливу $є$ варіативними, оскільки виробник залізорудної сировини, перебуваючи на першому етапі 
створення кінцевої продукції холдингу, залежить портфельної стратегії холдингу (пріоритет конкурентоспроможності металургійних підприємств) та його тарифної політики щодо послуг сервісних компаній холдингу. Тому, рентабельність продукції гірничо-збагачувального підприємства, асоційованого 3 холдингом $\left(\mathrm{R}_{X . \Gamma 3 \Pi)}\right)$ враховуватиме наступні складові, (формула 1):

$$
R_{x .23 n}=\frac{\Pi_{23 n}+\Pi_{x}+\Pi_{\kappa \kappa}}{C_{23 n} \pm B_{x}} 100 \%,
$$

де $\Pi_{2 з n}-$ прибуток ГЗП за основним видом продукції (залізорудний продукт 3 видобутої сировини), грн.; $\Pi_{x}-$ додатковий прибуток ГЗП синергетичної природи, забезпечений діяльністю сервісних підрозділів холдингу, грн.; $\Pi_{к \kappa}-$ прибуток від комплексного використання сировини ГЗП (попутні корисні копалини; залізорудний продукт 3 техногенних відходів), грн; $\mathrm{C}_{2 з n}$ - собівартість продукції без урахування $\left(\mathrm{B}_{\mathrm{x}}\right)$ синергетичних ефектів

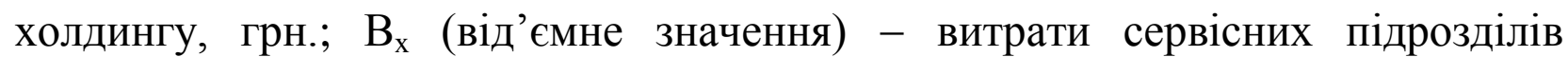
холдингу, що фінансуються 3 відокремленого бюджету та не додаються до витрат ГЗП, грн.; $\mathrm{B}_{\mathrm{x}}$ (позитивне значення) - сплата послуг підрозділів холдингу для гірничо-збагачувального комбінату, які за змістом $\epsilon$ аутсорсингові та збільшують собівартість продукції, грн.

Аналогічно можна модифікувати формулу розрахунку рівня беззбитковості асоційованого підприємства $\left(Б_{\Gamma 3 \Pi}\right)$, де доцільно враховувати прибуток від комплексного використання корисних копалин, тобто ефект багатономенклатурного виробництва (формула 2):

$$
\mathrm{Б}_{\Gamma з \Pi}=\frac{B_{n .23 n} \pm B_{x}-\prod_{K K}}{\bigsqcup_{\mathrm{x}}-\mathrm{B}_{3 \mathrm{M}}},
$$

де $Ц_{\mathrm{x}}$ - ціна продукції ГЗП; $\mathrm{B}_{3 м}, \mathrm{~B}_{n .2 з n}-$ змінні та постійні витрати асоційованого комбінату.

Як показали проведені дослідження, беззбитковий обсяг виробництва може бути знижений відповідно на $15-18 \%$, при цьому прибутковість підприємства зросте на 5-7\% (за укрупненими економічними параметрами підприємств Кривбасу).

Стан беззбитковості може бути оцінений коефіцієнтом самоокупності, а стан економічної безпеки - коефіцієнтом самофінансування [8]. В науковій площині існують різні підходи до визначення джерел походження інвестицій підприємства, але загально прийнятим $є$ спрямування нерозподіленого прибутку та амортизаційних відрахувань на потреби оновлення основних засобів підприємства 3 метою оптимізації виробничих потужностей. Тому, важливим $€$ розуміння кількісних параметрів виробничої та комерційної діяльності, які дозволяють стверджувати про досягнення підприємством стану самофінансування. Коефіцієнт самофінансування $\left(\mathrm{K}_{\text {сам }}\right)$ може бути 
розрахований, (формула 3):

$$
\kappa_{\text {caM }}=\frac{\Pi_{H}+A}{K+3}
$$

де $\Pi_{\mathrm{H}}-$ прибуток, який направляється в фонд накопичення, грн.; А - амортизаційні відрахування, грн./рік; К - залучені кошти, грн.; 3 - кредиторська заборгованість, грн.

$$
\Pi_{H}=\frac{\Pi_{u} \cdot K_{H}}{100},
$$

де Пч - чистий прибуток, грн.; $К_{\mathrm{H}}-$ коефіцієнт накопичення, \%.

Чистий прибуток можна записати так:

$$
\Pi_{\Psi}=\left[\left(L_{\kappa}-B_{3 M}\right) \cdot Q_{p}+\sum_{1}^{n} L_{i} \cdot Q_{i}-B^{\prime} n .23 n^{-A}\right\rfloor \cdot \beta,
$$

де $\mathrm{Q}_{\mathrm{p}}$ - обсяг реалізованої продукції, т.; $B^{\prime}$.гзи - постійні витрати без амортизаційних відрахувань, грн.; $\beta$ - коефіцієнт, що враховує норму податку на прибуток, що визначається: $\beta=(1-\Pi \Pi)$, де ПП - податок на прибуток, частка одиниці.

Чистий грошовий потік для оцінки самофінансування дорівнює:

$$
\text { ЧГП }=\left[\left(L_{\kappa}-B_{3 . м}\right) \cdot Q_{p}-B_{n .23 \kappa}^{\prime}\right] \cdot \beta+A\left(1-\beta \cdot K_{H}\right),
$$

Граничне значення обсягу реалізації продукції $\left(\mathrm{Q}_{\text {гр }}\right)$, при визначеному коефіцієнті самофінансування $\left(\mathrm{K}_{\text {сам }}\right)$ визначається, (формула 7$)$ :

$$
Q_{\text {гp }}=\frac{B_{n .23 n^{\prime}}^{\prime} \Pi_{\kappa}-\sum_{1}^{n} L_{i} \cdot V_{i}+\frac{K_{C \mathrm{am}}}{\beta \cdot K_{H}}(K+3)-A\left(\frac{1}{\beta \cdot K_{H}}-1\right)}{\mu_{\kappa}-B_{3 M}},
$$

де $L_{i}$ - ціна $i$-го виду продукції при комплексному використанні надр, грн; $\mathrm{V}_{i}$ - обсяг реалізованого $i$-го виду продукції, нат.од.

Проведені дослідження, показали, що зі зменшенням коефіцієнту самофінансування з 1,5 до 0,5 обсяг реалізації збільшується у середньому на $15 \%$.

Отримані аналітичні вирази (1-7) дозволяють оцінити граничні обсяги реалізації продукції, при яких підприємство самостійно фінансує власну господарську діяльність по відношенню до утвореної вартості. Таким чином, одним 3 критеріїв економічної безпеки підприємства $є$ обсяг реалізації продукції у вартісному виразі при виконанні якого не лише досягається беззбитковість, але й утворюється стала фінансова база технічного та технологічного оновлення [9].

Крім того, одним із напрямків забезпечення економічної безпеки ГЗП є 
створення стабілізаційного фонду. Для встановлення розміру стабілізаційного фонду введемо такий показник, як середньозважене значення коефіцієнту попиту, $\mathrm{K}_{\text {попиту }}$ (формула 8):

$$
K_{\text {nonumy }}=\frac{\sum_{i=1}^{n} K_{n_{i}} \cdot i}{\sum i},
$$

де $K_{\text {пі }}$ - коефіцієнт попиту за $i$ - період часу; $i$ - період час, за який встановлюється коефіцієнт попиту на продукцію, міс.

$$
K_{\Pi_{i}}=\frac{Q_{p_{i}}}{Q_{\text {без }_{i}}},
$$

де $\mathrm{Q}_{\mathrm{p}}$ - ринковий попит за $i$-період часу; $\mathrm{Q}_{\text {без }}$ - обсяг реалізації продукції за період часу на рівні беззбитковості, т.

Величина стабілізаційного фонду $\left(\mathrm{C}_{\mathrm{CT}}\right)$ визначиться, (формула 10$)$ :

$$
C_{C T}=\left[B_{n .2 з n_{c p}}^{\prime}+\frac{\Delta Д_{c p}+\Delta 3_{c p}-A \cdot \Pi \Pi}{(1-\Pi \Pi)}\right] \cdot\left(1-\kappa_{\text {nonит }}\right),
$$

де $\Delta Д_{\text {ср }}$ - середнє значення дебіторської заборгованості за аналізований період часу, грн.; $\Delta 3_{\text {ср }}$ - середнє значення кредиторської заборгованості за аналізований період часу, грн.; В грн.

Для розглянутого господарюючого суб'єкта (ПАТ «Центральний ГЗК») величина стабілізаційного фонду, в межах терміну (10 років) коливання попиту на продукцію може приблизно складати в середньому 15-18 млн. грн. Це створить можливість сталої роботи підприємства в умовах економічної нестабільності.

Висновок. Наукова новизна роботи полягає в розвитку методичних положень та підходів, щодо оцінки впливу синергії i комплексного використання сировини на економіку асоційованого гірничо-збагачувального підприємства. Теоретичне значення полягає в удосконаленні методичних підходів: визначення граничного (беззбиткового) обсягу видобутку основної сировини з урахуванням прибутку підприємства синергетичної природи $\mathrm{i}$ комплексного використання сировини з порід розкриву (щебінь) і збагачення (пісок); управління мінерально-сировинним потенціалом на базі формування стабілізаційного фонду для сталої роботи гірничо-збагачувального підприємства у довгостроковій перспективі. Практичне значення роботи полягає в тому, що запропоновані взаємозалежні показники дозволяють не лише оцінювати поточні параметри беззбиткової діяльності підприємства, але й прогнозувати його майбутній конкурентний статус серед подібних підприємств вертикально-інтегрованого холдингу. Напрямком подальшого 
дослідження є узагальнення та розвиток науково-методичних основ, розробка інструментарію оцінки ефективності роботи асоційованого гірничозбагачувального підприємства у довгостроковій перспективі на базі взаємозв'язку гірничо-технологічних та еколого-економічних параметрів та обмежених запасів природних ресурсів родовищ.

\section{Лiтература:}

1. Федорова Ю.В. Дослідження прояву синергетики в діяльності учасників промислово-фінансових груп / Ю.В. Федорова // Вісник Національного технічного університету «Харківський політехнічний інститут». Технічний прогрес і ефективність виробництва. - Харків: НТУ «ХПІ». - 2008. - №54 (3). - С.23-26.

2. Опис підприємства: ЦГОК [Електронний ресурс]. - Режим доступу: http://www.ukrrudprom.com/reference/factory/tsgok.html.

3. Опис бізнесу ПАТ «Центральний ГЗК» [Електронний ресурс]. - Режим доступу: http://smida.gov.ua/db/emitent/year/showform/83/227176.

4. Шагоян C.M. Конкурентоспроможність гірничо-збагачувального комбінату в складі корпоративного об'єднання / С.М. Шагоян // Міжвузівська науково-практична конференція «Теоретичні та прикладні аспекти становлення та розвитку конкурентоспроможної економіки». Кривий Ріг, 2011. - С. 154-156.

5. Регулярна інформація за 2004 рік. ПАТ "Центральний гірничозбагачувальний комбінат" [Електронний ресурс]. - Режим доступу: http://smida.gov.ua/db/emitent/old/arch/showform/2004/vat_194/00190977/6.

6. Холдинг «Метінвест». Наш бізнес. Гірничо-видобувний дивізіон. [Електронний ресурс]. - Режим доступу: http://www.metinvestholding.com/ua/activity/raw_iron.

7. Холдинг «Метінвест». Логістика. Метінвест-Шиппінг. [Електронний ресурс]. - Режим доступу: http://www.metinvestholding.com/ua/activity/logistics]

8. Савицкая, Г.В. Комплексный анализ хозяйственной деятельности предприятия: Учебник / Г.В. Савицкая. - М.: НИЦ ИНФРА-М, 2013. - 607 с.

9. Солодовник Л.М., Шагоян С.М. Граничне значення обсягів реалізації продукції на базі коефіцієнта самофінансування / Л.М. Солодовник, С.М. Шагоян // Проблеми і перспективи інноваційного розвитку економіки України [Текст]: матеріали міжнар.наук.-практ.конф., 31 трав. - 2 черв. 2012 р., м. Дніпропетровськ / ред. кол.: О.І. Амоша [та ін.] - Д.: Національний гірничий університет, 2012. - Т.1. - С.84-85. 